\title{
"Wase Glee": Dari Kearifan Hingga Kenaifan Lokal Para Peramu Hasil Hutan di Aceh
}

\author{
Pangeran P.P.A. Nasution \\ Program Studi Antropologi, FISIP, Universitas Malikussaleh \\ pangeran9688@gmail.com
}

\begin{abstract}
Local wisdom remained as an important discourse in the society. It directs mutual awareness of selfworth and respect for a lofty and sustainable local cultural treasury. This article describes 'Wase Glee', the cultural knowledge of forest product utilization in Aceh. Wase glee is a manifestation of local wisdom which includes guidelines and taboos (adat meuglee: adat encroachment) in Gampong Alue Bieng, Aceh Utara District, Aceh Province.'Wase glee' has been examined in the provisions of Qanun, the sharia-based regulation that revitalizes and reinforces indigenous institutions in Aceh society. It encompasses perspectives and activities which contain customary values. Ironically, the recognition of customary institutions which are accompanied by various arrangements of community activities creates an arbitrary slit by those in the customary authority. This article also aims to discuss local wisdom in environmental management especially related to forest resources, and also how the authority contained in the qanun that should present wisdom for the life of the community, it becomes a naive fact that tends to be exploitative. This paper is presented based on data obtained by qualitative research methods. Primary data was obtained from field research via interview (indepth) with categoryinformants: ureung meuglee (forest encroachers), traditional elders, and related gampong officials. The narrative notion in this paper refers to the ethno-sciences approach as the axis of analytic nodes present in the overall exposure of this article.
\end{abstract}

Keywords: Local Wisdom, Gatherer, Forest, Wase Glee, Ureung Meuglee

\begin{abstract}
Abstrak
Kearifan lokal adalah wacana penting dari kehidupan manusia yang hingga kini masih menjadi entitas sara budaya yang unggul dan menarik untuk diperbincangkan. Kearifan lokal mengarahkan kesadaran bersama manusia mengenai kepatutan diri dan penghargaan atas khasanah budaya lokal yang adiluhung dan lestari. Artikel memaparkan pengetahuan budaya peramu hasil hutan pada satu rumpun etnik di Indonesia, yaitu pada masyarakat Aceh yang mengenal Wase Glee (pemanfaatan hasil hutan) sebagai manifestasi kearifan lokal yang meliputi petunjuk anjuran dan pantangan (adat meuglee: adat merambah hutan) pada masyarakat Gampong Alue Bieng, Kabupaten Aceh Utara, Provinsi Aceh. Adat wase glee dicermati dalam ketentuan Qanun, regulasi berbasis syariah yang merevitalisasi dan menguatkan kembali kelembagaan adat pada masyarakat Aceh, meliputi cara pandang dan aktivitas yang mengandung nilai-nilai adat. Ironisnya, pengakuan lembaga adat yang turut disertai dengan berbagai pengaturan kegiatan masyarakat menciptakan celah kesewenangan oleh mereka yang memangku kewenangan adat. Artikel ini juga bertujuan membahas tentang kearifan lokal dalam pengelolaan lingkungan terutama yang berhubungan dengan sumber daya hutan, dan juga bagaimana kewenangan yang terdapat dalam qanun yang semestinya menghadirkan kearifan bagi kehidupan masyarakat, justru menjadi kenyataan naif yang cenderung eksploitatif. Artikel ini disajikan berdasarkan data yang diperoleh dengan metode penelitian kualitatif. Data primer diperoleh dari penelitian lapangan via wawancara (indepth) dengan kategori informan: ureungmeuglee (perambah hutan), tetua adat, dan aparat gampong terkait. Gagasan naratif dalam artikel ini mengacu pada pendekatan etnosains sebagai poros simpul analitik yang hadir dalam keseluruhan paparan artikel ini.
\end{abstract}

Kata kunci: Kearifan Lokal, Peramu hasil hutan, Wase Glee, Ureung 


\section{Pendahuluan}

Lingkungan hidup merupakan ruang kehidupan yang menyediakan berbagai kemungkinan bagi manusia untuk mengembangkan kebutuhannya. Berbagai upaya dilakukan manusia untuk mengantisipasi, menanggapi, dan menghadapi perubahan lingkungannya baik fisik maupun sosial demi mencapai pemenuhan kebutuhan hidup dan agar kelangsungan hidupnya tetap terjaga (Alland, 1975; Attfield, 2010; Awang, 2002; Lampe, 2006; Nasution, 2013; Sutton, 2004). Hutan adalah salah satu rupa lingkungan, yang berperan sangat penting sebagai pengendali keseimbangan ekosistem kehidupan manusia. Hutan menjadi pabrik utama dalam upaya penyerapan dan pengalihan energi dari cahaya matahari menjadi berbagai sumber daya energi lainnya yang dibutuhkan mahluk hidup (Amsikan, 2000; Poerwanto, 2008; Simon, 2000).

Manusia mengambil manfaat atas hutan. Bentuk manfaat hutan bagi kehidupan manusia dapat ditemukan dalam hubungan manusia dengan kawasan hutan sebagai bagian dari lingkungan hidup manusia. Hutan merupakan salah satu sumber utama ketersediaan oksigen bagi mahluk hidup, bahkan hutan secara metonimik dikatakan sebagai paru-paru bumi manusia. Hutan menjadi kawasan biosfer dengan diversitas hayati yang kompleks dan turut menjadi sangga kehidupan manusia. Kawasan hutan menyediakan beragam sumber daya alam yang bermanfaat besar bagi kesejahteraan manusia (Simon, 2000). Namun demikian, keberadaan hutan daya dukung hutan terhadap berbagai aspek kehidupan manusia, satwa, dan tumbuhan turut ditentukan oleh kesadaran dan kehendak manusia dalam mengelola dan memanfaatkannya. Kesadaran tentang keberadaan hutan salah satunya adalah memahami bahwa hutan sebagai ruang kehidupan yang menghendaki sinergitas antara manusia dan mahluk hidup lainnya maupun sumber daya lainnya yang dapat diperoleh dari hutan, relasi dan proses ekologis dalam tatatan siklus kehidupan manusia (Rahmawaty, 2004:2)
Kearifan lokal (local wisdom) sebagai 'sara budaya' masih menjadi rujukan pengelolaan hutan dimaksud. Kearifan lokal terbentuk karena adanya hubungan antara masyarakat tradisional dengan ekosistem disekitarnya, yang memiliki sistem kepercayaan, hukum dan pranata adat, pengetahuan lokal dalam mengelola sumber daya alam (Nababan, 1995). Masyarakat lokal di beberapa daerah di Indonesia mampu mengelola kawasan hutan dan sumberdaya alamnya dengan pengetahuan budaya dengan menghimpun kearifan local terkait pengelolaan hutan. Pengelolaan lingkungan, tatanan kerjanya diatur seksama dengan ketentuan adat yang instruktif (Setiawan, 2003).

Kearifan (wisdom) secara etimologi berarti kemampuan seseorang dalam menggunakan akal pikirannya untuk menyikapi suatu kejadian, objek atau situasi. Istilah lokal selanjutnya menyatakan relung interaksi di mana peristiwa maupun situasi berlangsung atau terjadi. Dengan demikian, kearifan lokal secara substansial merupakan norma yang berlaku, diyakini kebenarannya, dan menjadi acuan masyarakat dalam bertindak dan berperilaku. Kearifan lokal merupakan entitas yang sangat menentukan harkat dan martabat manusia dalam komunitasnya (Lubis, 2005).

Kearifan lokal sering juga diartikan sebagai kearifan masyarakat lokal atau tempatan (local wisdom), dan pengetahuan lokal (local knowledge) maupun kecerdasan yang dimiliki oleh suatu kelompok masyarakat tempatan Konsep kearifan lokal dimaknai sebagai pengetahuan yang khas milik suatu masyarakat atau budaya tertentu telah berkembang dalam durasi kehidupan yang panjang, terperiodik sebagai hasil dari proses hubungan timbal-balik antara manusia dengan lingkungannya (Li, 2012).

Kearifan lokal berkembang dengan cara-cara dan praktek-praktek yang dikembangkan manusia, dari pemahaman mendalam mereka akan lingkungan setempat/lokal. Diwariskan secara turun-temurun secara lisan atau melalui pengetahuan dan tindakan. Kearifan lokal berasal dari dalam masyarakat itu 
sendiri, disebarluaskan secara non-formal dan milik kolektif anggota masyarakat yang bersangkutan dalam sebuah kesatuan. Nilai-nilai dan pengetahuan lokal tertanam di dalam cara hidup masyarakat sebagai sarana untuk bertahan hidup (Orlove, 1980).

Secara esensial, kearifan lokal berisikan gambaran dan pengetahuan (kognitif) masyarakat tentang hal-hal yang berkaitan dengan struktur lingkungan, bagaimana lingkungan berfungsi, bagaimana reaksi alam atas tindakan manusia, serta hubungan-hubungan yang sebaiknya tercipta antara manusia dan lingkungan alamnya. Salah satu wujud dari pengetahuan mereka adalah terciptanya suatu sistem pengelolaan sumber daya alam. Berbagai tradisi, upacara adat, dan tindakan sehari-hari manusia mengandung makna yang dalam atas hubungan mereka dengan lingkungannya (Anderson, 2010). Selain itu, kearifan lokal secara defenitif merupakan pandangan hidup yang sudah mentradisi mengenai hubungan antar komunitas atau antar warga masyarakat dengan lingkungan hidup mereka. Lubis (2005) kemudian mendefinisikannya sebagai sejumlah pengetahuan kebudayaan yang berkenaan dengan modelmodel pemanfaatan dan pengelolaan sumber daya alam secara lestari. Namun demikian, kawasan hutan di sisi lain berparas ekonomi dengan pesona sumber daya alam bernilai tinggi: deretan pepohonan sebagai sumber penghasil komoditas kayu yang dianggap tak akan berkurang ketersediaanya, kehendak konversi hutan menjadi lahan pertanian, perkebunan, permukiman, industri dan lain sebagainya. Rangkaian konversi hutan yang terjadi dalam satu pandangan dominan dianggap bermula dari peningkatan jumlah penduduk yang signifikan. Meningkatnya jumlah populasi penduduk akan berkaitan dengan tuntutan pemenuhan kebutuhan pangan, kayu sebagai komoditas perumahan, dan perluasan areal permukiman (Simon, 2000).

Luas lahan pertanian yang dibutuhkan relatif terbatas dalam menjamin ketersediaan pangan menghendaki konversi kawasan hutan menjadi lahan pertanian dengan begitu gencarnya. Hutan memiliki nilai ekonomi sekaligus proteksi lingkungan yang saling kontradiktif. Pengelolaan yang tepat dan berimbang akan mewujudkan kehendak hidup manusia tanpa menggelar kerusakan hutan secara sporadis, namun ironisnya kenyataan itu berkelanjutan.

Begitu halnya dengan yang terjadi di Aceh pasca berakhirnya konflik GAM-RI ${ }^{1}$. Aceh merupakan provinsi dengan sumberdaya alam yang berlimpah, namun ironis, wilayah bangsa ini tidak luput dari catatan sejarah konflik yang menyertainya. Pemberontakan oleh kelompok pasukan bersenjata lokal (indigenous armed milition) terhadap pemerintah Republik Indonesia merupakan benih konflik yang ditaburkan sejak awal periode kemerdekaan, pada tahun 1940-an dan 1950-an. Pada periode kepemimpinan Soeharto, wilayah Aceh dikembangkan dari provinsi yang dianggap 'miskin' menjadi provinsi dengan optimisme pertumbuhan perekonomian tercepat di Indonesia. Namun, sebagian besar elit pemimpin masyarakat Aceh percaya bahwa mereka tidak mendapatkan bagian proporsional dari pertumbuhan ekonomi tersebut. Pandangan tersebut memicu perasaan anti-Jakarta dan meningkatkan popularitas Gerakan Aceh Merdeka (Gerakan Aceh Merdeka) di Aceh. Selama periode Soeharto (1966-1998) ada tiga isu politik dan ekonomi yang penting dan berkontribusi terhadap kerusakan hubungan antara Aceh dan Pemerintah Indonesia di masa Orde Baru: eksploitasi ekonomi, persaingan yang sedang berlangsung di Aceh antara pemimpin agama dan kaum bangsawan tradisional, dan perubahan politik serta ekonomi secara cepat yang terjadi di Indonesia pada masa Orde Baru (Sugiarti dan Purwadi, 2010).

Pasca runtuhnya rezim pemerintahan Soeharto disertai bergulirnya bandul reformasi dengan dinamikanya tersendiri telah mengantarkan Aceh pada momentum perdamaian yang digelar dalam MOUHelsinki di tahun 2005. Pada level tertentu, gelombang damai di Aceh membawa kehendak Islamisasi dengan anatomi, batas-

${ }^{1}$ GAM: Gerakan Aceh Merdeka. RI: Republik Indonesia. 
batas, dan geliat kekuasaan di Aceh pasca MOU-Helsinki. Tercipta elit pemerintahan baru di Aceh yang otonom dan mendesak independensi dengan arsitektur pemerintahan yang mencitrakan ketakwaan melalui UUPA (Undang-Undang Pemerintahan Aceh), dan berbagai peraturan daerah (Perda) bermetomini Islami yang dikenal dengan istilah Qanun. Regulasi berbasis syariah ini merevitalisasi dan menguatkan kembali kelembagaan adat pada masyarakat Aceh yang meliputi cara pandang dan aktivitas yang mengandung nilai-nilai adat.

Ironisnya, pengakuan lembaga adat yang turut disertai dengan berbagai pengaturan kegiatan masyarakat menciptakan celah kesewenangan oleh mereka yang memangku kewenangan adat. Oleh sebab itu, artikel ini bertujuan membahas tentang kearifan lokal dalam pengelolaan lingkungan terutama yang berhubungan dengan sumber daya hutan, dan juga bagaimana kewenangan yang terdapat dalam qanun yang semestinya menghadirkan kearifan bagi kehidupan masyarakat, justru menjadi kenyataan naif yang cenderung eksploitatif.

\section{Metode}

Artikel ini menguraikan kajian antropologis yang diperoleh dengan metode penelitian kepustakaan, wawancara, pengamatan nonpartisipan, dan dokumentasi. Penelitian pustaka dilakukan untuk memperoleh informasi awal serta referensi yang mendukung pemahaman terhadap fokus kajian, dan juga pengayaan perspektif pra-analitik terhadap data yang diperoleh dari penelitian lapangan. Berbagai sumber informasi awal artikel ini diperoleh dari buku, jurnal, artikel, tesis maupun disertasi, hasil laporan penelitian, dokumen pemerintah, dan berbagai informasi dari berbagai media berita cetak maupun elektronik.

Rangkaian data diperoleh dari wawancara terhadap informan biasa dan informan kunci. Pemilihan informan ditentukan dengan konteks informasi yang hendak digali. Sebagaimana dikemukakan Spradley (2007), para informan ditentukan berdasarkan beberapa syarat minimal: enkulturasi penuh, keterlibatan langsung informan dengan suasana budayanya, latar belakang budaya yang berbeda dengan peneliti, ketercukupan waktu, dan non analitik.

Wawancara ditujukan untuk mengungkap informasi yang terkait dengan kejadian, sejarah dan persepsi. Wawancara juga dilakukan untuk merekam informasi yang dianggap mampu memberi gambaran historis atas fenomena yang berlangsung selama beberapa kurun waktu. Selain itu, observasi non-partisipan turut digunakan terutama untuk mengamati berbagai perilaku, tindakan, dan peristiwa lainnya yang terkait dengan aktivitas budaya pengelolaan hutan dan pemanfaatan sumber daya hasil hutan.

\section{Hasil dan Pembahasan}

Uraian mengenai sara budaya dalam pengelolaan hutan maupun sumber daya hutan di dalam artikel ini merujuk pada satu kelompok masyarakat Paya Bakong di Aceh, tepatnya di Gampong Alue Bieng. Kehidupan mereka secara keseluruhan bergantung pada sumber daya hutan, dan kelangsungan hidup mereka terhubung dengan bagaimana mereka memanfaatkan lingkungan hutan sebagai cagar biosfer. Kehidupan sosial, ekonomi, dan budaya mereka secara askriptif dengan lingkungan hutan telah berlangsung dalam periode waktu yang lampau dan masih terus berlangsung hingga kini.

Narasi dalam artikel ini merupakan hasil penelitian di tahun 2015 pada masyarakat Gampong Alue Bieng yang lokasi pemukimannya dikelilingi oleh kawasan hutan. Masyarakat Gampong Alue Bieng umumnya menyandarkan kehidupannya pada usaha perladangan dan pemanfaatan hasil hutan. Secara administratif, Gampong Alue Bieng termasuk dalam wilayah Kecamatan Paya Bakong, Kabupaten Aceh Utara, Provinsi Aceh. Paya Bakong berasal dari kata paya yang dalam bahasa Aceh merupakan kata lain dari alue yang berarti anak sungai, dan 
kata bakong/ bakoeng yang berarti tembakau. Dengan demikian, paya bakong dapat diartikan sebagai daerah 'anak sungai' di kawasan hutan yang di sekitarnya terdapat tumbuhan tembakau.

Paya Bakong ditetapkan sebagai wilayah kecamatan yang otonom pada tahun 2002. Ibukota Kecamatan Paya Bakong adalah Gampong Keude Paya Bakong yang berjarak sekitar 18,5 km dari Kota Lhoksukon yang merupakan Ibukota Kabupaten Aceh Utara. Secara geografis, Kecamatan Paya Bakong mempunyai wilayah seluas $418,32 \mathrm{~km}^{2}$ yang berbatasan dengan wilayah:

$\rightarrow$ Utara : Kecamatan Matang Kuli

$\rightarrow$ Selatan: Kabupaten Aceh Tengah

$\rightarrow$ Barat : Kecamatan Meurah Mulia dan Tanah Luas

$\rightarrow$ Timur : Kecamatan Pirak Timu dan Cot Girek

Pemanfaatan lahan dari keseluruhan luas wilayah Kecamatan Paya Bakong dapat diketahui pada tabel berikut:

Tabel 1. Luas Wilayah Kecamatan Berdasarkan Pemanfaatan Lahan

\begin{tabular}{|c|l|c|}
\hline No. & \multicolumn{1}{|c|}{ Wilayah } & $\begin{array}{c}\text { Luas Lahan } \\
\text { (Ha) }\end{array}$ \\
\hline 1. & Pemukiman & 10.000 \\
\hline 2. & Perkebunan & 4.059 \\
\hline 3. & Sawah & 1.429 \\
\hline 4. & Ladang & 2.900 \\
\hline 5. & Padang Rumput & 125 \\
\hline 6. & Hutan Rakyat/Negara & 35.798 \\
\hline 7. & Perikanan Rakyat & - \\
\hline 8. & Lain-lain & 11 \\
\hline
\end{tabular}

Sumber: Kecamatan Paya Bakong dalam Angka, 2013.

Populasi penduduk Kecamatan Paya Bakong berjumlah 13.430 jiwa dengan kepadatan penduduknya pada tahun 2013 diketahui hanya sebesar 30,84 jiwa $/ \mathrm{km}^{2}$. Pemukiman penduduk menyebar di 39 desa/gampong (dalam Bahasa Aceh). Setiap gampong dipimpin oleh seorang Geuchik (Kepala Pemerintahan Desa). Gampong Alue Bieng sendiri memiliki populasi yang terdiri dari 130 Rumah Tangga dengan penduduk berjumlah 547 jiwa, terbagi atas 275 jiwa Laki-laki dan 272 Jiwa Perempuan. ${ }^{2}$

\section{Wase Glee: Risalah Kearifan Lokal Peramu Hasil Hutan}

Aceh sebagai satu wilayah etnik di Indonesia memiliki kesatuan masyarakat dengan hukum adat yang mengatur berbagai sendi kehidupan. Pengakuan masyarakat adat termaktub dalam Pasal 98 Ayat (1) UndangUndang Nomor 11 Tahun 2006 tentang Pemerintahan Aceh, dan juga dalam Pasal 2 ayat (1) Qanun Aceh Nomor 10 Tahun 2008, menyatakan keberadaan dan fungsi Adat Istiadat secara terlembaga di Aceh. Lembaga adat berfungsi mengorganisir petunjuk anjuran dan juga dalam penyelesaian sengketa adat di Aceh. Kelembagaan adat di Aceh, terutama yang membidangi masalah pengelolaan hutan merupakan sara budaya atau manifestasi unggul dari kearifan lokal (local wisdom) dan pengetahuan lokal (local knowledge) yang masih dimiliki dan diterapkan oleh masyarakat Aceh secara umum.

Begitu juga dengan masyarakat di Gampong Alue Bieng. Bagi Masyarakat Alue Bieng, sumber daya hutan yang membentang di kawasan perbukitan dan pegunungan merupakan anugerah dari sang pencipta. Kesadaran yang berlanjut turun-temurun diwariskan guna merawat ingatan bersama tentang manfaat hutan bagi kelangsungan hidup masyarakat.

"Sejak masa endatu geutanyoe sampoe jinoe hat geutanyoe manteng sa mewasee ngen hasil alam lam uteun Tuhan nyoe. Uteun di sinoe ka lagee syiruga anugerah dan titepan Poe teuh Rabbi."

"Sejak masa leluhur kita sampai sekarang, hutan merupakan anugerah Tuhan. Kawasan hutan di sini bagaikan "surga" titipan Allah yang berrmanfaat bagi kita”.

${ }^{2}$ Data Kecamatan Paya Bakong dalam Angka, Tahun 2013. 
Begitulah lisan pengetahuan masyarakat Gampong Alue Bieng dalam memandang keberadaan hutan sebagai bagian dari lingkungan hidup mereka. Kesadaran mengelola lingkungan secara arif berasal dari tradisi lisan para Endatu (leluhur) yang termanifestasi dalam sistem pengetahuan dan pola tindakan masyarakat, dipatuhi sebagai norma dan melekat dalam kehidupan mereka. Kesepakatan nilai yang dipatuhi masyarakat sebagai adat pantang ${ }^{3}$.

Kearifan lokal masyarakat Gampong Alue Bieng dalam mengelola dan memanfaatkan sumber daya hutan dikenal dengan istilah Wasee Glee. ${ }^{4}$ Seluruh aktivitas meramu hasil hutan merupakan bagian dari adat pantang yang diawasi oleh Panglima Uteun atau Pawang/Kejruen Glee, sebutan bagi seseorang yang berperan sebagai tetua adat bidang kehutanan yang kedudukannya berada di bawah Imam Mukim ${ }^{5}$.

Kejruen Glee merupakan tetua adat yang mengawasi urusan pengelolaan dan pemanfaatan hasil hutan, berupa kayu maupun non kayu (madu, getah rambung, sarang burung, rotan, damar, dll). Selain itu, Kejruen Glee berperan memberi nasehat atau petunjuk dalam pengelolaan hutan, dan menyelesaikan perselisihan dalam pelanggaran adat Wase Glee/ pemanfaatan hasil hutan.

Masyarakat Gampong Alue Bieng mencari beragam sumber daya hutan pada siang hari setelah menyelesaikan aktivitas berladang yang dilakukan dari pagi hari. Mereka memasuki hutan untuk mendapatkan berbagai hasil hutan dari siang hingga sore hari. Hasil hutan yang biasanya dicari di antaranya adalah rotan dan madu. Sebilah parang dan eumpang (karung) merupakan

\footnotetext{
${ }^{3}$ Adat Pantang adalah sistem tradisi dalam masyarakat Aceh terkait dengan berbagai jenis anjuran dan pantangan dalam melakukan suatu aktivitas tertentu.

${ }^{4}$ Kawasan hutan dalam istilah lokal disebut dengan Meuglee.

${ }^{5}$ Imam Mukim merupakan istilah adat di Aceh yang berartiPemangku adat yang pada kesatuan masyarakat hukum adat yang terdiri dari beberapa gampong dengan batas-batas wilayah tertentu.
}

peralatan utama yang lazim dibawa dalam mencari hasil hutan. Bekal makanan yang dibawa hanya berupa buah-buahan. Apabila haus, mereka mendapatkan sumber air minum dari batang rotan muda dan maupun buah yang mengandung kadar air tinggi.

Pada saat masyarakat membutuhkan hasil hutan dalam jumlah lebih banyak, mereka bisa menjelajah hutan hingga satu minggu dengan mengajak serta pawang glee sebagai pemandu di dalam hutan. Rute yang dilintasi ketika berada di hutan adalah mengikuti raueh (jalan setapak) yang sudah ada sebelumnya. Apabila hendak membuka rute lintas hutan yang baru, maka, harus mendapatkan persetujuan oleh Pawang Glee. Jika suatu ketika mereka tersesat di dalam hutan, maka, pertanda alam menjadi acuan navigasi. Sebagai misal, dengan memperhatikan jenis akar-akaran yang melilit di atas pohon, atau dengan mengikuti jejak harimau yang dianggap sebagai petunjuk jalan keluar hutan.

Mencari hasil hutan biasanya dilakukan warga ketika kondisi hasil dari berladang memasuki musim paceklik, atau ketika hasil ladang belum bisa dipanen. Dalam periode kalender Masehi, kegiatan mencari hasil hutan biasanya dilaksanakan pada akhir tahun (November atau Desember) dan awal tahun (Januari atau Februari). Adat Pantang dalam wasee glee juga mengatur larangan melakukan kegiatan mencari hasil hutan pada hari Jum'at dan Hari Rabu Abeh. Larangan pada Hari Jum'at disebabkan paham budaya tempatan bahwa Jum'at sebagai hari peribadatan yang sakral dengan Ibadah Shalat Jumat secara massif. Kemudian larangan pada Hari Rabu Abeh adalah Hari Rabu terakhir atau pada minggu keempat dalam satu bulan. Rabu Abeh diberlakukan karena dianggap sebagai hari tabu dengan sangkaan potensi musibah yang besar bagi mereka yang memasuki hutan.

Adat wase glee juga mengatur tentang penebangan pohon di hutan yang akan dimanfaatkan untuk menghasilkan kayu yang bernilai ekonomi. Ada beberapa jenis pohon yang tidak boleh ditebang. Sebagai misal, 
pohon meurebu (merbau; Intsia Spp.), keutapang (ketapang; Terminalia Catappa), glumpang (kelumpang; Sterculia Foetida), meurante (meranti; Shorea), dan pepohonan lainnya yang dianggap masih muda. Beberapa jenis tersebut dilarang ditebang karena diketahui sebagai media bersarangnya lebah dan akan menghasilkan madu yang menjadi salah satu sumber daya hasil hutan bernilai ekonomi tinggi. Jenis pepohonan yang diperbolehkan ditebang di antaranya adalah pohon alen/gaharu atau pepohonan yang dianggap sudah tua.

Keunikan dari penebangan pohon diatur dalam wase glee, yaitu "pengembalian jasad pohon”. Apabila pohon telah tumbang, penebang pohon diharuskan mengambil lima ranting dari pohon tersebut untuk ditancapkan kembali pada bidang atau tapak pohon bekas tebangan. Tindakan ini dimaksudkan sebagai pengganti pohon yang ditebang. Wase glee juga mengatur larangan penebangan pohon yang terdapat di sepanjang daerah aliran sungai (krueng) atau alue (anak sungai), lereng gunung, dan lembah karena berfungsi sebagai daerah resapan dan penyangga bagi bencana banjir ketika musim penghujan.

Bentuk kearifan dalam wase glee juga ditemukan dalam rangkaian ritual adat khanduri uteun ${ }^{6}$ berupa makan bersama di dalam hutan. Lokasi pelaksanaan khanduri uteun disesuaikan dengan kawasan hutan yang akan dijelajahi untuk mengambil hasil hutan. Beberapa perangkat yang dipersiapkan untuk melaksanakan khanduri uteun adalah tikar sebagai alas berkumpul, dan juga peralatan memasak hidangan makanan khanduri. Hewan kurban berupa ayam tidak luput sebagai hidangan utama yang disantap bersama seluruh peserta khanduri uteun. Setelah makan bersama, mereka akan berdoa: "diawali dengan Bismillah..., kemudian membaca Al Fathihah sebanyak tiga kali,

\footnotetext{
${ }^{6}$ Khanduri Uteun adalah upacara adat yang dimaksudkan untuk menghalau masyarakat dari musibah ketika berada di hutan. Upacara ini juga bertujuan agar mendapatkan rezeki yang baik dari sumber daya hasil hutan.
}

dan diakhiri dengan Shalawat". ${ }^{7}$ Doa yang dipanjatkan dalam acara khanduri uteun, selain sebagai wujud syukur terhadap Allah SWT, sang pencipta, ditujukan juga sebagai terimakasih kepada para endatu (leluhur) atas keberadaan hutan yang dianggap merupakan keuneubah endatu (warisan leluhur).

Penyembelihan ayam sebagai hewan kurban merupakan bentuk sedekah masyarakat atas hasil hutan yang mereka peroleh. Selain karena alasan efisiensi biaya yang berkaitan dengan kondisi ekonomi masyarakat, pemilihan ayam sebagai hewan kurban ternyata memiliki alasan kultural yang lekat lainnya. Ayam menjadi pilihan hewan kurban untuk menghindari ketegangan sosial di antara warga yang secara umum juga melakukan aktivitas ekonomi sebagai peternak kambing. Apabila kambing digunakan sebagai hewan kurban, maka, dikhawatirkan menyebabkan terciptanya per-saingan sedekah hewan kurban yang dapat memicu saling gunjing di antara warga. Sementara dengan memilih ayam dan membelinya di pasar, maka, dapat mengantisipasi ketegangan sosial dimaksud.

Pada pelaksanaan wase glee, ketika berada di hutan, warga harus mematuhi adab meuglee, yaitu aturan menjaga lisan, pikiran, perkataan hati, dan perbuatan dari segala sesuatu yang bersifat buruk. Begitu pun ketika akan membuka areal perladangan baru di sekitar kawasan hutan, diharuskan melaksanakan adat uteun (baca: adat hutan) berupa tradisi peusijeuk uteun (pesejuk hutan). Sebagai misal, setidaknya tiga hari sebelum areal hutan dirambah, dilaksanakan upacara adat yang dimaksudkan untuk menghalau dan meminta segala jenis makhluk hidup di luar manusia, seperti hewan dan bahkan mahluk gaib (jin, setan, dan sejenisnya) yang dianggap menetap di areal hutan tersebut untuk berpindah tempat. Peusijeuk uteun bertujuan menciptakan ketentraman dan kemakmuran bagi masyarakat dalam pemanfaatan sumber daya hasil hutan.

\footnotetext{
${ }^{7}$ Lafalan doa ini merupakan bagian dari kesadaran religitas Islam yang merupakan Agama yang dianut secara dominan oleh masyarakat di Aceh.
} 
Peusijeuk uteun dilaksanakan di tengah areal hutan yang akan digarap dan prosesinya dipenuhi dengan seruan tradisi lisan pemindahan mahluk hidup, misalnya hewan yang berada di sekitarnya akan berpindah lokasi dan tidak akan turut terbakar ketika areal dibersihkan dan dibakar. Prosesi adat ini juga dihadiri oleh Peutua Seuneubok ${ }^{8}$. Di awal prosesi pembukaan areal hutan, peutua seuneubok akan terlebih dahulu memotong bagian dari salah satu pohon untuk mendapatkan kayu berukuran kecil berjumlah tujuh batang, dan ketujuh kayu tersebut tidak boleh jatuh menyentuh tanah. Pelaksanaan pemotongan kayu oleh peutua seuneubok dipercaya dapat menjaga masyarakat yang membuka ladang terhindar dari musibah. Selain itu, ada juga larangan untuk tidak memotong ureut $^{9}$ yang melilit di pohon karena dipercaya akan mendatangkan hewan yang membahayakan, ular misalnya.

Beberapa pantangan lainnya bagi para Ureung Meuglee (peladang) juga turut diberlakukan, misalkan, dilarang melakukan kegiatan pem-bersihan semak-belukar ketika hujan atau pada periode keuneng sa, yaitu musim hujan dengan curah hujan yang tinggi. Pantangan ini diberlakukan karena dipercaya akan memicu kehadiran hama belalang. Begitu juga dengan adanya larangan 'buang air besar/BAB' di dalam hutan yang dipercaya dapat menyebabkan hadirnya hama yang serupa, yaitu belalang maupun ulat.

Adat uteun lainnya juga mengatur pantangan dalam aktivitas berladang di kawasan hutan yang berkaitan dengan alat berladang. Misalkan, larangan menancapkan parang atau benda tajam sejenisnya pada batang pohon maupun tunggul pohon. Pantangan ini di-maksudkan agar menjauhkan para peladang di sekitar kawasan hutan terhindar dari bala dan bencana. Tidak hanya itu, para peladang juga dilarang menggantungkan sejenis kain maupun pakaian berladangnya pada dahan maupun ranting pohon. Jika

\footnotetext{
${ }^{8}$ Seseorang yang memimpin dan mengatur ketentuan tentang pembukaan dan penggunaan lahan dalam kegiatan berladang.

${ }^{9}$ Sejenis akar-akaran yang melilit pada pohon.
}

dilanggar, maka, para peladang dipercaya akan mengalami gagal panen ladang maupun ketika melaksanakan wate glee (mengambil hasil hutan).

Bagi mereka yang tidak mematuhi petunjuk maupun perihal yang telah diatur dalam wase glee, dipercaya akan mendapatkan musibah dan tidak memeroleh hasil baik ketika mengambil hasil hutan. Menghindari kemungkinan musibah yang dapat dialami oleh pelanggar adat wase glee, maka, harus segera dilaksanakan acara Khanduri Selamatan sebagai peusijuk (penyejuk; pembersihan diri). Khanduri Selamatan biasanya dilaksanakan di kawasan hutan yang diperkirakan menjadi lokasi pelanggaran wase glee, namun bisa juga dilaksanakan di meunasah gampong (Mesjid Kampung/ Desa). Biaya pelaksanaan kenduri selamatan tersebut ditanggung oleh pihak pelanggar adat.

Seluruh perlengkapan yang dibutuhkan akan dibawa serta ke lokasi pelaksanaan khanduri Selamatan. Bukan hanya pawang glee maupun peutua seuneubok yang hadir dalam acara khanduri selamatan, pihak pelanggar wase glee harus turut mengundang para ulama atau Imam Meunasah ${ }^{10}$ setempat. Prosesi utama dari acara khanduri selamatan adalah pengajian dan doa bersama. Setelah itu di akhir acara akan dilaksanakan makan bersama oleh seluruh peserta yang hadir. Warga gampong juga turut diundang untuk menghadiri khanduri selamatan agar mereka tidak melakukan perihal serupa dalam adat wase glee.

Pemberian sanksi adat juga bisa diberlakukan bagi pelanggar adat wase glee. Bentuk sanksi akan diputuskan melalui duek pakat/ musyawarah atau sidang adat perangkat gampong. Usulan sanksi yang disepakati akan disampaikan oleh Peutua Seuneubok kepada seluruh tetua adat yang hadir dalam acara khanduri selamatan. Rangkaian acara khanduri selamatan secara keseluruhan bermakna

\footnotetext{
10 Imam Meunasah adalah seseorang yang memimpin kegiatan masyarakat di gampong yang berkaitan dengan urusan keagamaan, Islam, dan juga yang berkaitan dengan pelaksanaan syari'at Islam.
} 
sebagai bentuk pernyataan maaf dan penutup malu bagi pelanggar adat.

\section{Ureung Meuglee: Risalah Kenaifan Lokal Perambah Hutan}

Pengakuan masyarakat adat di Aceh yang termaktub dalam Pasal 98 Ayat (1) UndangUndang Nomor 11 Tahun 2006 tentang Pemerintahan Aceh, dan juga dalam Pasal 2 ayat (1) Qanun Aceh Nomor 10 Tahun 2008, tentang keberadaan dan fungsi Adat Istiadat secara terlembaga di Aceh telah melampaui kehendak kearifan melalui kewenangan yang melekat padanya, terutama kaitannya dengan adat pengelolaan sumber daya hutan. Para tetua adat, seperti Kejruen Glee yang semestinya berperan memberi nasehat atau petunjuk dalam pengelolaan hutan, dan menyelesaikan perselisihan dalam pelanggaran adat Wase Glee/ pemanfaatan hasil hutan, justru kini diketahui menjadi penjamin bagi Ureung Meuglee yang semula adalah masyarakat peramu hasil hutan berdaya lestari terhadap hutan, kini menjadi para perambah hutan yang sangat eksploitatif dalam memenuhi hasrat ekonomis. Wase glee yang berisi kearifan lokal sebagai upaya pelestarian hutan jangka panjang, telah terabaikan akibat dominasi kepentingan ekonomi pasar atas komoditi kayu hasil hutan. Umumnya kini masyarakat telah bermufakat menguras hutan dengan beragam cara, dan bahkan bekerja sama dengan para pemegang hak konsesi hutan.

Peutua Seuneubok yang semestinya berperan memimpin dan mengatur tentang pembukaan dan penggunaan lahan dalam kegiatan berladang, kini turut andil dalam merambah hutan sebagai penunjuk jalan dan mengawal kegiatan penebangan pohon di hutan secara ilegal. Apa yang disebut dengan penebangan liar maupun pembalakan haram justru kini semakin marak terjadi dengan berlindung atas nama adat.

Praktik para tetua adat yang mematut hasil hutan pada ekonomi pasar sepertinya tidak lagi sebatasfiguran belaka dalam pentas ekonomi pasar, namun turut sebagai aktor penentu. Satu argumen kunci dari pernyataan tersebut adalah bagaimanaureung meuglee (perambah hutan) di Alue Bieng bukanlah semata penerima pasif dari sebab-sebab global melainkan turut memainkan peran aktif dalam membentuk kembali dan menghasilkan proses komodifikasi hasil hutan dengan cara tak terduga. Kini "yang lokal” dan "yang global” bukanlah dimensi yang terpisah, namun lebih merupakan hasil yang mengikat satu dengan yang lain.

Pemaknaan secara kritis tentang ruang, tempat, dan kekuasaan ataskeberadaan qanun, dapat dilihat bagaimana qanun turut tereksploitasi memicu proses sosial yang membuka kemungkinan adanya ruang bagi aktor sosial untuk melakukan manuver, menafsirkan, serta membuat pilihan dan keputusan. Para tetua adat, seperti Kejruen Glee dan Peutua Seuneubok merupakan agensi yang meskipun dengan kewenangan terbatas, namun turutberperan aktif dalam mengeksploitasi sumber daya hutan. Serangkaian praktik, tempat dan hubungan, dapat memperjelas bagaimana proses komodifikasi hasil hutan yang lebih luas dibangun melalui praktik "lokal", dan bagaimana orang-orang "lokal” (ureung meuglee) terlibat di dalamnya.

\section{Simpulan}

Salah satu sara budaya dalam kehidupan masyarakat Gampong Alue Bieng tercermin dalam kearifan lokal dalam meramu hasil hutan, dikenal dengan istilah wase glee. Kearifan lokal dimaksud meliputi petunjuk anjuran dan pantangan. Petunjuk tentang ritual adat, doa keselamatan dan kemakmuran, dan rangkaian pandangan dan tindakan magis terhadap berbagai pertanda alam guna menciptakan keseimbangan hidup manusia dan mahluk gaib (superstition) terkait aktivitas pemanfaatan hasil hutan. Sementara itu, 'adat pantang' mengatur berbagai larangan: bersikap angkuh, adab meuglee, penebangan sembarang terhadap jenis pohon tertentu dan pada waktu dan tempat yang tabu. 
Kearifan lokal yang diwariskan secara turuntemurun oleh endatu (leluhur) tampak dalam aktivitas pengelolaan kawasan hutan untuk berladang (meuglee). Misal, anjuran pelaksanaan khanduri glee dalam prosesi pembukaan,pembersihan lahan, dan panen. Pengetahuan yang mengatur tentang waktu lazim maupun tabu dalam melaksanakan wase glee, misalnya pada Hari Jumat dan Rabu Abeh. Rangkaian kearifan lokal dalam meramu hasil hutan merupakan sara budaya unggul bagi masyarakat Gampong Alue Bieng dalam meningkatkan taraf hidup tanpa beresiko merusak keseimbangan dan kelestarian hutan sebagai cagar biosfer mereka. Meskipun demikian, realitas kehidupan masyarakat dalam pemanfaatan hasil hutan tidaklah seromantis atau seindah sebagaimana yang dipaparkan. Kini semakin banyak ditemukan warga yang melanggar ketentuan adatmeuglee tersebut. Motif kepentingan ekonomi pasar, sangkaan budaya kekinian yang memosisikan adat sebagai entitas usang, minimnya pengalaman dan tergerusnya kesadaran terhadap nilai kearifan lokal, memicu laju perambahan hutan secara sembarang dan tak berdaya lestari dalam kurun tahun terakhir.

\section{Daftar Pustaka}

Alland, A. Jr.(1975). 'Adaptation'. Annual Review of Anthropology (Vol. 4), pp. 59-73.

Amsikan, Y.G. (2000). Kearifan Ekologi Masyarakat Biboki (Suatu Kajian Etnoekologi). Tesis Antropologi. Yogyakarta: Universitas Gadjah Mada.

Anderson, Katie E. (2010). 21st Century Anthropology: A Reference Handbook Volume 1 \& 2. California: Sage Publications.

Attfield, R. (2010). Etika Lingkungan Global. Yogyakarta: Kreasi Wacana.

Awang, S.A., dkk. (2000). Etnoekologi Manusia di Hutan Rakyat. Yogyakarta: SINERGI Press.

Lampe, M. (2006). Pemanfaatan Sumber Daya Taka oleh Nelayan Pulau Sembilan: Studi tentang Variasi Perilaku Nelayan dan Konsekuensi Lingkungan dalam Konteks Internal dan Eksternal. Disertasi Antropologi. Yogyakarta: Universitas Gadjah Mada.
Li, Tania M. (2012). The Will to Improve: Perencanaan, Kekuasaan, dan Pembangunan di Indonesia. Bintaro: Marjin Kiri.

Lubis, Zulkifli B. (2005). 'Menumbuhkan (Kembali) Kearifan Lokal dalam Pengelolaan Sumberdaya Alam di Tapanuli Selatan'. Jurnal Antropologi Indonesia, Vol. 29 (3), 239-254.

Nababan, A. (1995). 'Kearifan Tradisional dan Pelestarian Lingkungan Hidup di Indonesia: Kebudayaan, Kearifan Tradisional, dan Pelestarian Lingkungan'.Jurnal Analisis CSIS, Vol. XXIV, No. 8.

Nasution, Pangeran P.P.A. (2013). 'Pokok Hari Nyalah:Catatan Budaya (Lokal) dalam Membaca Perubahan Iklim (Global)'. Jurnal Antropologi Indonesia, Vol. 34 (2), 152-163. Juli-Desember 2013.

Orlove, B.S. (1980). 'Ecological Anthropology'. Annual Review of Anthropology (Vol. 9),pp. 235-273.

Poerwanto, H. (2008). Kebudayaan dan Lingkungan dalam Perspektif Antropologi. Yogyakarta: Pustaka Pelajar.

Rahmawaty. (2004). Hutan: Fungsi dan Peranannya Bagi Masyarakat. Medan: Universitas Sumatera Utara (USU) Digital library.

Setiawan, B. (2003). Globalisasi Pertanian: Ancaman atas Kedaulatan Bangsa dan Kesejahteraan Petani. Jakarta: IGJ-Institute for Global Justice.

Simon, H. (2000). Hutan Jati dan Kemakmuran: Problematika dan Strategi Pemecahannya. Yogyakarta: BIGRAFF Publishing.

Spradley, James P. (2007). Metode Etnografi. Yogyakarta: Tiara Wacana Yogya.

Sugiarti, E., dan Purwadi, B. (2010). "Anak Keluarga Korban Konflik Aceh: Collective Memory Masyarakat Aceh”. Laporan Hibah Penelitian Kerjasama Antar Perguruan Tinggi (Hibah Pekerti). Tahun Anggaran 2010. Universitas Airlangga, Surabaya.

Sutton, M.Q. \& Anderson, E.N. (2004). Introduction to Cultural Ecology. USA: AltaMira Press.

Qanun Aceh Nomor 10 Tahun 2008 tentang Lembaga Adat. 